apportioning blame, and look coolly at both the excessive outrage of feminists and the unsavoury underreaction of gynaecologists. Coolness, however, is always relative. Although the book tries to be objective, there is a repeated dramatic emphasis on the 'irony and horror' of trying to improve pregnancy outcome by giving a teratogen. The case-histories tend to be extreme (a girl who asks her gynaecologist if she, like her mother, should use a douche, gets the reply: 'Mom just douches for jollies'), and psychological problems are described in purple prose, with lurid references to 'turmoil', 'brutality', 'sobbing', 'rage', 'hate', 'struggle' and 'terrible pain'. As psychoanalysts, the authors believe that everyone seethes with unconscious emotion - though some people 'suppress' it completely. They do not acknowledge that psychoanalysts, no less than other physicians, have a vested interest in finding disease where none exists.

The other area of introspection left unexplored is the fact that the DES story is a peculiarly American one. The drug was discovered by the British Medical Research Council, but relatively few British doctors prescribed DES in pregnancy. Dr Apfel and Dr Fisher discuss medical aspirations in cosmic terms, implying that across the globe doctors were universally adored until the DES experience shattered patients' trust, but in fact the DES story tells us something about the American character as well as about the nature of medicine. Nevertheless, it would be wrong to be smug because of British conservatism. This book, despite its earnestness and exaggerations, has a useful message for doctors and by and large puts it over tactfully and effectively. But will those who need the lesson read the book?

JAMES OWEN DRIFE Senior Lecturer, Department of Obstetrics and Gynaecology, University of Leicester

\section{What Sort of People Should There Be?}

Jonathan Glover, 190 pages, Harmondsworth, UK, £2.50, Penguin, 1985

It is the fate of scientists to have their work and their methodology explained to them by philosophers, while the possible problems they may unleash upon the world are also regarded by philosophers, theologians and writers of science fiction as being essentially in their province. It is also the fate of philosophers to meet with approval from a few scientists, with irritation from some and with total indifference from most. Nevertheless not all scientists are uninterested in the ethics and social implications of their work. Many scientists have publicly taken ethical stands which owe nothing to the promptings of moral philosophers. It was scientists who were concerned about genetic engineering and pressed for standards and safeguards to govern future research in these areas. It was scientists who warned that the indiscriminate use of antibiotics in agribusiness would lead to the appearance of resistant forms of organisms which infect humans. It is scientists who are warning us of nuclear winter. Those scientists who are not interested in such issues when their own colleagues raise them are unlikely to be moved by moral philosophers.

To whom, then, is Dr Glover's book directed? If it is to the lay public, it would surely be helpful to distinguish clearly between the imaginative, the possible and the likely.

Readers of science fiction will know that most of the possible scenarios have been tested out already. We may take a few well known and well presented examples which deal with personality change and manipulation, or with genetic modification and species crosses - all themes in Dr Glover's book. The issues which might arise if human subhuman hybrids were made, the ethics of the use of primitives, groups with low or limited intelligence, and of animals, are explored in the novel Les Animaux Dénaturés by Vercors: aspects of sexuality and the possible psychological and social consequences of sex changes, whether regular, as in The Left Hand of Darkness by le Guin, or at will, as in Options by Varley; genetic optimisation by Brunner in Total Eclipse and in Stand on Zanzibar - a book which also considers the development and use of techniques for control and manipulation of the mind and personality (for military purposes, in this case) - also a theme in Haldeman's By All My Sins Remembered. When I read Dr Glover's non-fictional, decent, humane and earnestly informed treatment of these problems I felt less enlightened than by these works of fiction. I was irritated, often, by his inclusion of all imaginable outcomes; wholesale extrapolations from current techniques without consideration of the biological realities and the contexts in which biological systems operate - (yet there are occasional disarming paragraphs admitting that a lack of social content might indeed vitiate some of his arguments). Why am I unable to react favourably to this book? It is not the minor errors of fact, although there are some: for example he refers to spina bifida as a genetic mistake (p 31) but there is no clear evidence for a genetic component in this condition (although it is unlikely indeed that there is none) He says sickle cell anaemia is genetically linked to resistance to malaria ( $p$ 35) but 'genetic linkage' has a precise and specific connotation and this statement is simply incorrect. Nor does he see that clones would pose no new problems concerning individuality - we are already accustomed to this genetic phenomenon, in identical twins. The dissatisfaction stems rather from the tenor of the book as a whole. Clear though the arguments, are, they remain within limits and strictures that make the book a mere exercise, without any feeling of reality or urgency.

Certainly he has done homework on the basic approaches of genetio engineering, yet the discussion is affected by beliefs and postulates, some of which appear to be unconciously held. These include an apparent belief that resources and skilled personnel to manipulate them are inexhaustively available, a certain innocence concerning the regulation of gene expression, and a failure to recognise the existence and nature of randomness and error. He considers the objections to committees of experts having power over our genetic fate and that of our offspring by deciding which genes may or may not be inserted into the fertilised egg, fetus or individual (this he calls the 'Russian' model) and considers his alternatives: a 'genetic supermarket' which, driven by consumer demand, and presumably subject to market forces, '. . . (perhaps with genotypes being sold by TV commercials) can be thought of as an "American" model' or a 'genetic supermarket' with a few critically determined limitations on choice 'the mixed system' (which) 'may appeal to Western social democrats ...' (p 51). This 'genetic supermarket' would, he suggests, enable anyone to decide to have his or her offspring improved by the insertion of desirable genes. Presumably in the 'American' system the better the gene the higher the price; and the less affluent would have to make do with cut-price varieties. However, we cannot 
extrapolate linearly from the concept of replacing a defective allele by a functional one to the notion of superlatively functional or desirable varieties of gene. We can imagine the usefulness of inserting a gene into a haemophiliac, to produce adequate levels of factor VIII in serum. What would a better factor VIII gene do? Produce ten times as much? - and if so, would this be a good thing? Genes with effects on anatomy, behaviour or intelligence contribute to phenotypic effects in the context of interactions, at biochemical, cellular and tissue levels, with other genes in the individual and with the environment. An allele which confers advantage in one genetic and environmental context can make a neutral or negative contribution in others. For a range of reasons, most genes would require to be inserted in the egg. The necessity would then be to identify and obtain the appropriate gene, to identify the genotype of the egg, to insert the gene correctly, and to reimplant the egg, and it will be necessary to have total success at all stages of the manipulations. This is not merely a question of technique chemical reactions and cell interactions are stochastic processes: randomness and error are inbuilt, and cannot be eliminated. We have not yet domesticated Maxwell's demon. How would Dr Glover advise on the disposal of failed experiments? No, don't hope to buy a gene off the shelf to produce a super-person. Far better concentrate on making conditons possible for an enriched environment - we already know that this can produce remarkable results.

We must also consider resource allocation. We already have the means of identifying well over 200 genetically disadvantageous conditions in the fetus. Identification followed by termination has significantly reduced the numbers of individuals suffering from, for example, Tay-Sachs disease, or thalassaemia. The availability of skilled practitioners and or resources for this technique is nowhere near commensurate with need - yet it is far less demanding in all respects and has fewer chances of accumulating errors than would genetic salvaging or improvement of each suboptimal fetus. It is also more appropriate to the problems of our overcrowded planet. Genetic engineering is more likely to be useful for the production of specific gene products, or for certain conditions which might be managed by, for example, modified bone-marrow cells, or for animals or plants which may then be propagated indefinitely afterwards under controlled conditions. It is worth remembering, however, that there will be chemical and physiological limits to the milk yield of a cow, or the numbers of ears of corn on a maize plant.

Dr Glover's concern with possible future methods of modifying personality or behaviour will surely strike a chord with all his readers - yet personality and behaviour are already powerfully affected by such factors as the exercise of power, or by being victim and powerless, by deprivation, by the formation of mobs, by expected social roles, by rigid upbringing, and by skilled manipulation of public and private opinion and responses. We know through Amnesty reports of procedures developed and used in many countries to damage the character and spirit and to modify behaviour. Recently there have been first-hand reports from Vietnam veterans who were trained for 'special missions' in the so-called 'Boot camps' in the USA by horrific techniques of personality alteration so that they became murderous automata and are now unable to live as social beings, but remain isolated in the American wilderness.

Changes for the better in the future are more likely to be brought about by focusing on social structures, economics, education, and indeed, the whole of the human ecology. The horrors of the future are more likely to be averted by attention to the politics of the present, than by raising the eyes above the problems of today and gazing instead into the infinite void.

RUTH CLAYTON Reader, Department of Genetics, Edinburgh University, West Mains Road, Edinburgh 9

\section{Artificial Reproduction: a Social Investigation}

\section{R Snowden, G D Mitchell and E M Snowden, 155 pages, London, £9.95, George Allen and Unwin, 1983.}

The authors here record the results of their joint research project which, they say, has 'concentrated on the most common form of artificial reproduction, namely, artificial insemination by donor semen (AID)'.
But, they add, 'our interests have also extended to the social issues surrounding other forms of artificial reproduction'. They begin by describing the different ways of achieving procreation without engaging in sexual intercourse, and go on to propose a whole range of new technical terms for describing the agents and techniques involved. For example, they suggest 'genetic mother' for the woman who provides and matures the ovum, 'carrying mother' for the woman who brings the child to birth, and 'nurturing mother' for the woman who takes care of the child once it is born. They also recommend that the phrase 'in vitro fertilisation' be scrapped in favour of 'external human fertilisation'; but while their case for this substitution (p 29) is plausible, the former phrase is so widespread now that I suspect the authors are championing a lost cause here.

Chapter Three, on The Family, is important and valuable. The authors argue that 'we have two essential ingredients when describing family life: first, an exclusive sexual relationship, and secondly the birth, nurturance and upbringing of children. Family and marriage are thus concerned primarily with issues surrounding reproduction' (p 44). They regard these two characteristics as so essential to marriage, and marriage itself as so indispensable to the good of society, that they recommend that artificial reproduction, in whatever form, should take place only when the couple nurturing the child are married (p 169).

In Part II of the book the authors describe their research project, which involved studying the experiences of 899 couples who underwent AID treatment between 1940 and 1980, and interviewing 66 couples who are the parents of one or more AID children. How have people coped with infertility? Why is male infertility popularly invested with much more of a stigma than is female infertility? Do couples with AID children try to keep those children's origins from them as well as from close relations and friends? Should they do so, or is such secrecy itself a cause of anxiety which should be removed? The authors explore all these questions and many more, arguing that openness towards AID children and towards close relations and friends is the policy which produces the best results in terms of the peace of mind and freedom from stress of both parents and children.

The final two chapters, Artificial Reproduction and Society, and 